\title{
IMPACT OF DIETARY EICOSAPENTAENOIC AND DOCOSAHEXAENOIC FATTY ACIDS SUPPLEMENTATION ON INFLAMMATORY RESPONSE OF POST CALVING COWS DURING TRANSITION TO LACTATION
}

\author{
Shaimaa Elbaz ${ }^{1}$, Eldsokey Nassef ${ }^{2 *}$, Abdelnasser Bakr², Elsayed Hegazi², \\ Abeer M. S. EL-Keredy ${ }^{1}$
}

\begin{abstract}
${ }^{1}$ Department of Biochemistry, Nutritional deficiency diseases and Toxicology, Animal health Research Institute, Kafrelsheikh, Egypt, ${ }^{2}$ Nutrition and Clinical Nutrition Department, Faculty of Veterinary Medicine, Kafrelsheikh University, Egypt
\end{abstract}

*Corresponding author, E-mail: dsokeynassef@yahoo.com

\begin{abstract}
The aim of current study was to determine the effect of dietary omega 3 fatty acids (FA) mainly eicosapentaenoic (EPA) and docosahexaenoic (DHA) on inflammatory response of post calving cows during transition to lactation. Twenty Holstein lactating cows were assigned into two groups (10 each). The two groups fed on the basal diet while one of them was supplemented with $70 \mathrm{~g}$ of omega-3 FA per cow. The supplement was added to the diet from the $1^{\text {ST }}$ day of calving till the $60^{\text {th }}$ days of lactation. Blood samples were taken 3 times weekly from the $2^{\text {nd }}$ to the $4^{\text {th }}$ week post calving. The blood samples were analyzed for glucose, insulin, non-esterified fatty acids (NEFA), beta hydroxyl butyric acid (BHBA), C- reactive protein (CRP), haptoglobin, albumin and globulin. Feeding omega-3 FAs significantly increased $(\mathrm{P}<0.05)$ blood glucose level by $17.35 \%, 28.23 \%$ and $24.73 \%$ than the control at weeks $1,2,3$ of the experiment, respectively. BHBA was lower in cows fed omega-3 at $1^{\text {st }}$ and $2^{\text {nd }}$ week then became nearly similar to the control at the end of experiment. At $1^{\text {st }}$ and $2^{\text {nd }}$ week, cows fed omega-3 FAs had significantly lower serum CRP than those fed the control diet and became nearly similar to control at the end of the experiment. Serum, globulin was significantly higher in cows fed omega 3 FAs at $2^{\text {nd }}$ and $3^{\text {rd }}$ week by $81.1 \%$ and $51.2 \%$, respectively. Omega 3 FA improved energy status of fresh cow by increasing serum insulin and glucose levels while decreasing NEFA and BHBA parameters. Also, feeding omega 3 FA improved humoral immunity through increasing serum globulin and reduced inflammatory response by lowering CRP post calving.
\end{abstract}

Key words: omega 3 fatty acids; lactating cow; inflammation; energy balance; serum protein

Introduction

Received: January 2019

Accepted for publication: February 2019
The onset of lactation is one of the most critical period affecting dairy cows in which massive changes and more metabolic stresses for 
dairy cows (1). In this period there is high demand for energy for milk synthesis and secretion accompanied by changes in blood metabolites (2). The impaired glucose production that occurs in early lactating cows would lead to an increase in the breakdown of adipose tissue, elevated plasma NEFA and increased ketones production by the liver. After parturition by few several weeks there is more incidence of diseases and morbidity on many dairy cows with especially mastitis, metritis, milk fever, ketosis and fatty liver.

Postpartum dairy cow is suffering from systemic inflammatory state even with the absence of clinical disease (3). On the other hand, physiological changes that occurring in the fresh period after calving can affect cellular immune responses and modulate the influence of dietary fatty acids on immune functions. Also, the elevated NEFA leading to abnormal immune cell functions, increased inflammation and increased risk of metabolic and infectious diseases. The elevated plasma NEFA impaired cytokine production (4) and altered endothelial cell adhesion (5).

One of the different nutritional approach to decrease inflammation post calving is the use of omega 3 polyunsaturated fatty acids. It is thought that the n-3 fatty acids attenuate inflammatory response in lactating dairy cows (6) and eicosapentaenoic (EPA) and docosahexaenoic (DHA) have more immunomodulatory activities $(7)$. $(8,9)$ reported that EPA and DHA performing anti-inflammatory functions via direct or indirect inhibitory mechanisms. A reduction of inflammatory cytokine production with feeding of EPA and DHA to dairy cows and therefore they have the ability to modulate the inflammatory response this was reported by (6). One effect of cytokines is to activate production of acute phase proteins, that primarily produced by the liver, this class of proteins includes haptoglobin, serum amyloid A and C-reactive protein. The importance of acute phase proteins in the response to infection is somewhat unclear, but they have gained wide spread acceptance as markers of inflammation. (10) stated that cell surfaces receptors were more directly characterized mediate anti-inflammatory effects of omega-3 fatty acids. An attenuated inflammatory response was observed by (11) due to increase intake of EPA and DHA fatty acids which resulted in increase the proportion of these FAs in the membrane phospholipids. (12) noticed an increased plasma glucose and decreased plasma ketones when feeding omega 3 source compared to omega-6 sources in fresh cows in addition to anti-inflammatory effect of omega 3 due to increased phagocytic activity of circulating leukocytes. An increase in plasma glucose level was reported by (13) with feeding omega 3 polyunsaturated fatty acids. The improvement in metabolic profile with omega-3 fatty acids supplementation may be the key to beneficial effect on both immunity and inflammation. From the economic point of view, (14) reported that as the diet enriched in n-3 fatty acids, the nutrient expenditure would be reduced as omega-3 fatty acids attenuate the inflammatory responses.

This study aimed to evaluate the anti-inflammatory effect of EPA and DHA fatty acids in the post calving cows during transition to lactation. Also, their effects on energy balance were determined.

\section{Materials and methods}

\section{Cows and dietary treatment}

Twenty Holstein cows (10 multiparous and 10 primiparous) were assigned to two groups according to parity, body weight (BW) and previous milk yield (expected milk yield for primiparous cows). Cows averaged $680 \mathrm{~kg}$ of BW at the beginning of the experiment (post calving date). Cows had continuous access to fresh clean water. A basal postpartum TMR was formulated to meet or exceed (15) recommendation. Ingredients and nutrients composition are presented in Tables 1 and 2, respectively. Analysis of TMR on dry matter basis is presented in Table 3.

Cows were fed three times daily at 4 am, 11 am and $4 \mathrm{pm}$ for ad libitum intake. Treated group was top-dressed on the TMR and hand mixed at the time of feeding $70 \mathrm{gm} / \mathrm{head} /$ day with omega 3 FA supplement (STRATA G113) which its composition was fish oil $90 \%$, calcium $9.95 \%$ and BHT (antioxidant ) $0.05 \%$. 
The supplement was added at a rate $40 \mathrm{gm} / \mathrm{cow}$ at $4 \mathrm{am}$ and $15 \mathrm{gm} / \mathrm{cow}$ for each feeding $11 \mathrm{am}$ and $4 \mathrm{pm}$.

The typical analysis of fatty acids using gas chromatograph for STRATA G113 were: palmitic acid (16:0), 39.4\%; palmitoleic acid (16:1), 6.8\%; stearic acid (18:0), 9.9\%; oleic acid (18:1), 18.8\%; linoleic acid (18:2), 6.1\%; linolenic acid (18:3), 2.2\%; eicosapentaenoic acid (20:5), 10.3\%; docosahexaenoic acid (22:6), $6.5 \%$.

\section{Experimental measures and samples analy-} sis

Daily feed intake and refusal were recorded daily. Feed and refusal samples were collected daily, subsamples weekly, and composite at the end of experiment. TMR and feed refusal were immediately frozen.

The subsamples of TMR and feed refusal were dried at $60^{\circ} \mathrm{C}$ in hot air circulations oven (Heraeus UT 20 model, Germany). The dried samples of TMR, corn silage and other feed ingredients used were ground through $1 \mathrm{~mm}$ screen of grinder (Cyclotec 1093 Foss, Sweden).

The ground samples were analyzed for final dry matter at $105{ }^{\circ} \mathrm{C}$ for 3 hour, crude protein (Kjeltec system 2100-Foss, Sweeden), ether extract (Soxtec system 2045 Foss-Sweeden), and ash (Furnace6000, Thermolyne USA) according to (16). Neutral detergent fiber without using sodium sulfite, acid detergent fiber (ADF) (17) and lignin were determined by digesting the ADF residue in $72 \%$ sulfuric acid, (18). Fiber fractions were determined with fibertec M61020-Foss Sweden. Neutral detergent insoluble crude protein (NDICP) was determined after NDF extraction by analyzing the residue for crude protein. The NFC concentration was calculated using the following equation: $\mathrm{NFC}=100-(\mathrm{NDF} \%+\mathrm{CP} \%+\mathrm{EE} \%+\mathrm{Ash} \%)$.

The values of TDN and NEL were determined according to (15) based on nutrient analysis (CP, NDF, ADF, NFC, EE, Lignin, NDICP and ADICP). Total aflatoxins (B1, B2, G1 and G2) level was analyzed fluorometrically using VICAM series 4 USA according to (19).

Blood metabolites and hormones
Blood samples were collected from all animals at 11:00 am, 3 times weekly at the $2^{\text {nd }}, 3^{\text {rd }}$ and $4^{\text {th }}$ weeks postpartum. Ten $\mathrm{ml}$ of blood was collected from coccygeal vessel and divided into 2 tubes for each cow. One tube contained K2EDTA for plasma separation and the other tube was without anticoagulant for serum separation. Plasma was separated immediately after the collection of blood by centrifugation at $3000 \mathrm{rpm}$ for 10 minutes. The clear plasma was obtained using sterilized pipettes and kept at $20{ }^{\circ} \mathrm{C}$ till analysis. Serum was separated by blood centrifugation at $3000 \mathrm{rpm}$ for 15 minutes and then stored at $-20{ }^{\circ} \mathrm{C}$ till analysis.

\section{Biochemical analysis}

The collected plasma was analyzed for glucose according to (20) based on glucose oxidase enzyme activity. Plasma NEFA concentration was measured according to (21) using diagnostic reagent for quantitative in vitro determination of NEFA in plasma on photometric systems. Concentration of plasma BHBA was determined according to (22) using quantitative determination of B-hydroxy butyrate in plasma for in vitro diagnostic use Pointe Scientific, INC. Serum was analyzed for total protein according to (23) using quantitative method based on the intensity of the color formed which is proportional to the total protein concentration in the sample. Albumin was measured in serum according to (24) based on bromocresol green binding method using available commercial albumin kits. Globulin was calculated according to (25) by subtraction of albumin from total protein. Haptoglobin was measured according to (26) based on determination of serum hemoglobin binding capacity. $\mathrm{C}$ reactive protein (CRP) was measured in serum according to (27) based on Rete Nephelometry. Insulin was measured in serum according to (28) based on a solid phase enzyme-linked immunosorbent assay (ELISA).

\section{Statistical analysis}

The obtained data were analyzed using statistical software (SPSS Version 16). Group means were compared using analysis of T-independent-Samples $T$ Test. Levene's test for equality of variances was used to indicate the 
significance. The means were considered different at $\mathrm{P}<0.05$.

\section{Results}

Results of blood insulin, glucose, NEFA and BHBA concentrations are shown in figures 1, 2, 3 and 4, respectively. Cows fed omega-3 FAs had significantly $(\mathrm{P}<0.05)$ higher blood insulin level $(0.37$ and $1.1 \mathrm{mIU} / \mathrm{ml})$ than those fed the control diet $(0.17$ and $0.33 \mathrm{mIU} / \mathrm{ml})$. This trend lasted to 2 weeks then declined to be non-significant at $3^{\text {rd }}$ week of experiment $\left(4^{\text {th }}\right.$ week post calving). Feeding omega-3 FAs increased blood glucose level (mg/dl) by $17.35 \%, 28.23 \%$ and $24.73 \%$ than the control at weeks 1,2, 3 of the experiment, respectively. This was more significant at $2^{\text {nd }}$ and $3^{\text {rd }}$ weeks. Cows fed omega 3 FAs had significantly higher blood NEFA (mg/dl) at $1^{\text {st }}$ week and then rapidly declined at $2^{\text {nd }}$ week and became numerically lower but non-significant than the control at $3^{\text {rd }}$ week of experiment. In contrast, BHBA ( $\mathrm{mg} / \mathrm{dl})$ was lower in cows fed omega-3 at $1^{\text {st }}$ and $2^{\text {nd }}$ weeks then became nearly similar to the control at the end of experiment.

Results of CRP, haptoglobin, albumin and globulin concentration in serum are shown in figures 5, 6, 7 and 8, respectively. At $1^{\text {st }}$ and $2^{\text {nd }}$ weeks, cows fed omega-3 FAs had significantly $(\mathrm{P}<0.05)$ lower serum CRP $(0.27$ and 0.21 $\mathrm{mg} / \mathrm{L})$ than those fed the control diet $(0.37$ and $0.36 \mathrm{mg} / \mathrm{L}$ ) and became nearly similar to the control at the end of the experiment. Cows fed omega 3 FAs had no significant difference between the control and the experimental cows on serum haptoglobin and serum albumin along the experiment. In contrast, serum globulin was significantly higher in cows fed omega 3 FAs at $2^{\text {nd }}$ and $3^{\text {rd }}$ week which increased by $81.1 \%$ and $51.2 \%$, respectively, than the control. While at the $1^{\text {st }}$ week serum globulin was nearly similar in between the control and the experimental cows.

Table 1: Ration ingredients used for early lactating cows during the experiment

\begin{tabular}{lccc}
\hline Ingredients & DM\% & $\begin{array}{c}\text { DM } \\
\text { Kg/day }\end{array}$ & $\begin{array}{c}\text { As fed } \\
\text { Kg/day }\end{array}$ \\
\hline Cor each cow & & 7.41 & 26.45 \\
Wheat straw & 28.0 & 0.39 & 0.43 \\
Corn grain ground dry & 92.0 & 4.61 & 5.24 \\
Wheat bran & 88.0 & 0.76 & 0.86 \\
Soybean meal 46\% & 88.8 & 3.26 & 3.62 \\
Soy Best & 90.0 & 0.97 & 1.09 \\
Megalac & 89.0 & 0.45 & 0.47 \\
Optigen & 97.0 & 0.04 & 0.04 \\
Calcium carbonate & 99.0 & 0.20 & 0.20 \\
Salt white & 99.5 & 0.08 & 0.08 \\
Sodium bicarbonate & 99.5 & 0.21 & 0.21 \\
Vitamin mineral premix* & 99.5 & 0.06 & 0.06 \\
\hline
\end{tabular}

Premix provides $5500 \mathrm{IU}$ vitamin A; $500 \mathrm{IU}$ vitamin D; $50 \mathrm{IU}$ vitamin E; $100 \mathrm{mg}$ zinc; $60 \mathrm{mg}$ iron; $40 \mathrm{mg}$ manganese; $20 \mathrm{mg}$ copper; $0.6 \mathrm{mg}$ iodine; 0.3 selenium and $0.25 \mathrm{mg}$ cobalt per $\mathrm{kg}$ dry matter. 
Table 2: Nutrients composition of the basal diet

\begin{tabular}{lcc}
\hline Nutrient & DM & As fed \\
\hline Dry matter (\%) & 100.00 & 47.99 \\
Forage (\%) & 41.62 & 19.97 \\
Crude protein (\%) & 17.98 & 8.63 \\
Rumen undegradable protein (\% of CP) & 37.01 & 17.76 \\
Rumen degradable protein (\% of CP) & 62.99 & 30.23 \\
Soluble protein (\% of CP) & 27.89 & 13.38 \\
Metabolizable energy (Mcal/kg) & 2.60 & 1.25 \\
Net energy for maintenance (Mcal/Kg) & 1.69 & 0.81 \\
Net energy for gain (Mcal/kg) & 1.08 & 0.52 \\
Acid detergent fiber (\%) & 19.25 & 9.24 \\
Neutral detergent fiber (\%) & 30.17 & 14.48 \\
Forage neutral detergent fiber $(\%)$ & 23.39 & 11.22 \\
Lignin (\%NDF) & 8.44 & 4.05 \\
Lignin (\%DM) & 2.55 & 1.22 \\
Non fiber carbohydrate (\%) & 38.75 & 18.60 \\
\hline
\end{tabular}

Table 3: Analysis of total mixed ration on dry matter basis

\begin{tabular}{lcc}
\hline Nutrients $(\%)$ & As fed basis & Dry matter basis \\
\hline Dry Matter & $46.47975 \%$ & $100 \%$ \\
Moisture & $53.52025 \%$ & 0.00 \\
Crude Protein & $8.12 \%$ & $17.47 \%$ \\
Neutral detergent fiber & $16.8 \%$ & $36.14 \%$ \\
Acid detergent fiber & $10.1 \%$ & $21.73 \%$ \\
Cellulose & $8.61 \%$ & $18.53 \%$ \\
Hemicellulose & $6.7 \%$ & $14.41 \%$ \\
Lignin & $1.48 \%$ & $3.19 \%$ \\
NDICP & $1.44 \%$ & $3.1 \%$ \\
ADICP & $0.61 \%$ & $1.31 \%$ \\
Crude Fat & $1.48 \%$ & $3.19 \%$ \\
Ash & $3.81 \%$ & $8.21 \%$ \\
Non fiber carbohydrate & $16.27 \%$ & $35 \%$ \\
Total digestible nutrients & $32.48 \%$ & $69.8865 \%$ \\
DE (Mcal/kg) & 1.56 & 3.17 \\
ME (Mcal/kg) & 1.25 & 2.54 \\
NEL (Mcal/kg) & 0.79 & 1.6 \\
\hline ADICP acid & &
\end{tabular}

ADICP, acid detergent insoluble crude protein; NDICP, neutral detergent insoluble crude protein. DE, digestible energy; ME, metabolizable energy; NEL, net energy for lactation 


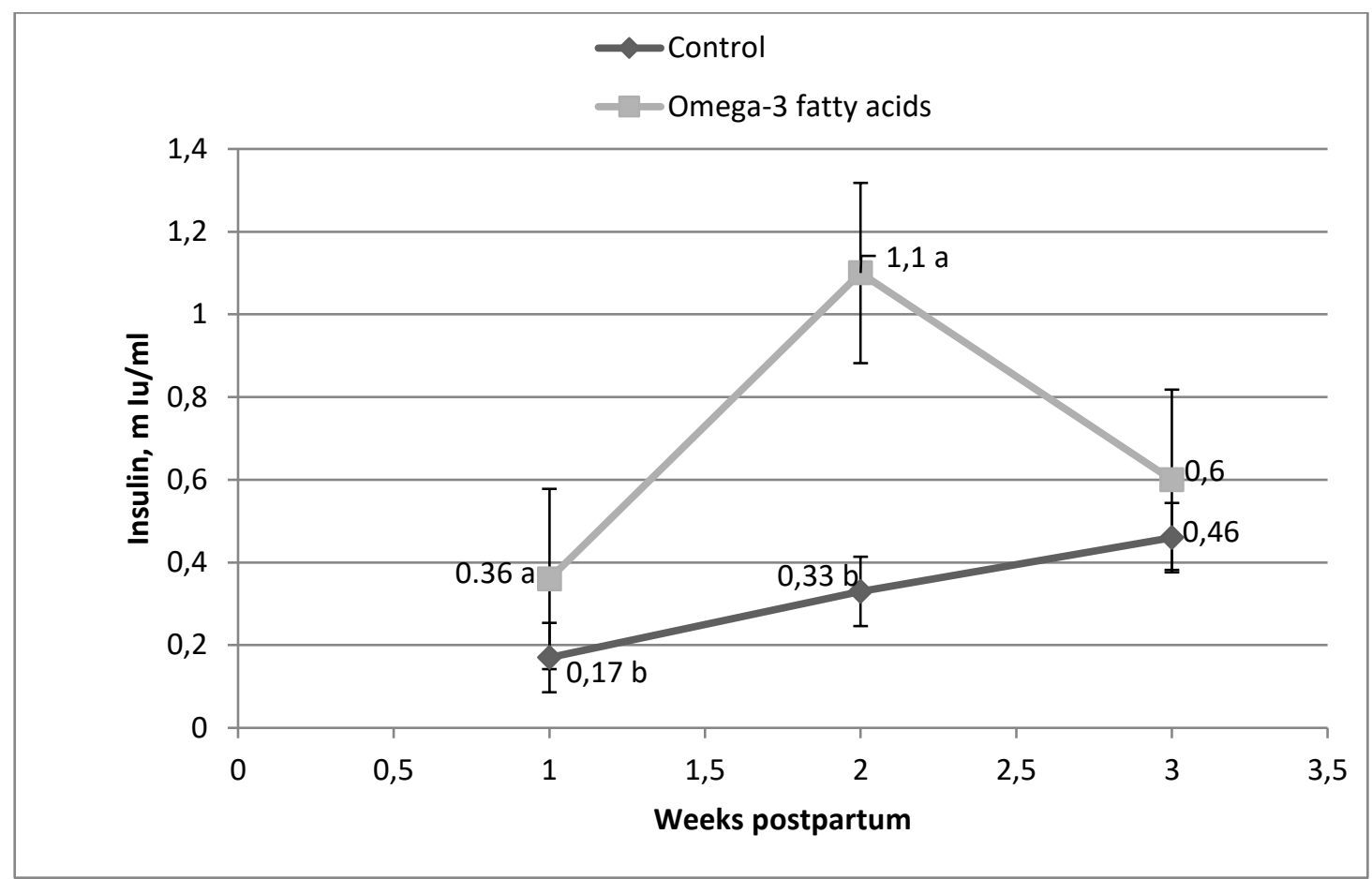

Figure 1: Influence of dietary omega-3 fatty acids on plasma concentrations of insulin in fresh lactating cows

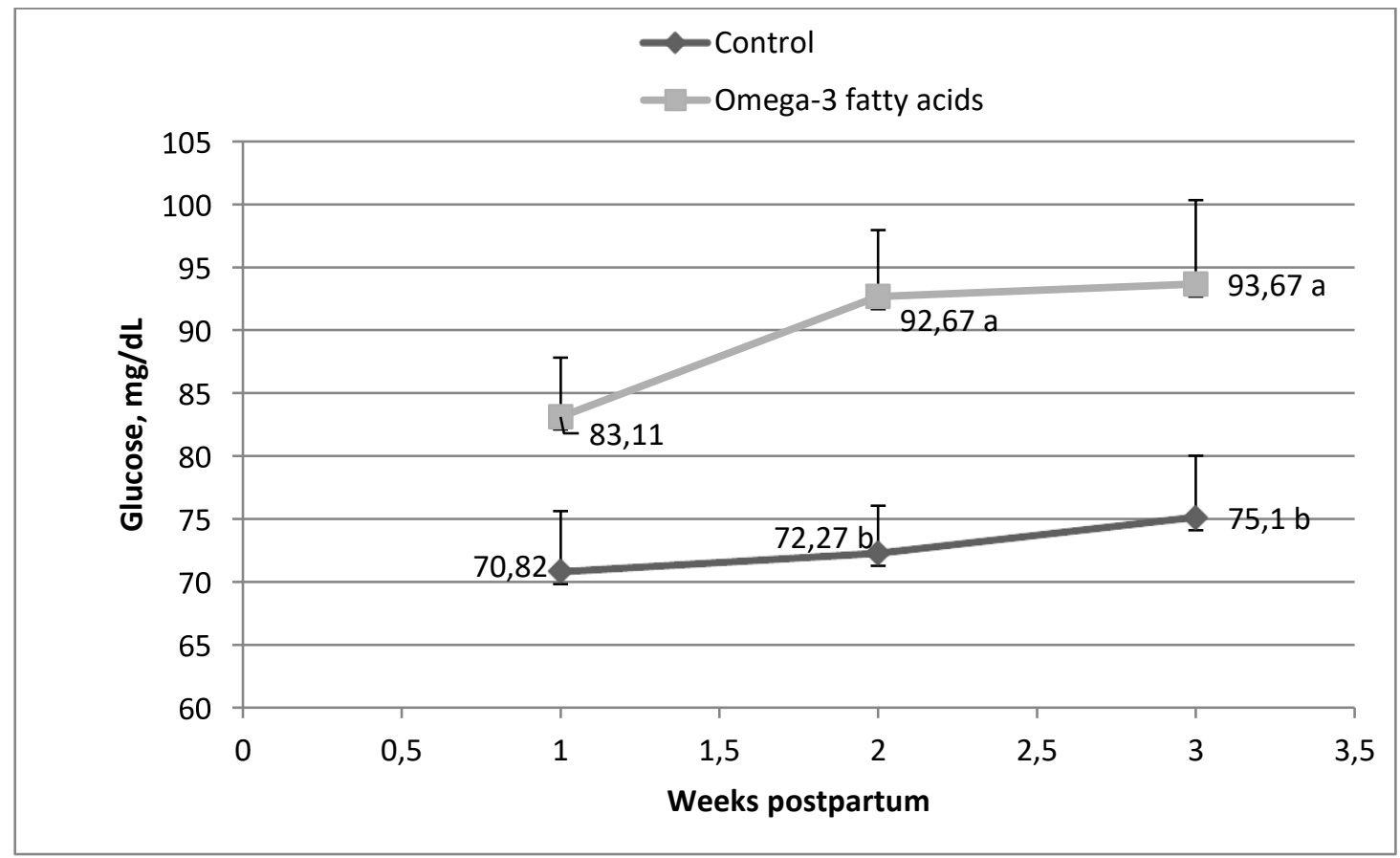

Figure 2: Influence of dietary omega-3 fatty acids on plasma concentrations of glucose in fresh lactating cows 


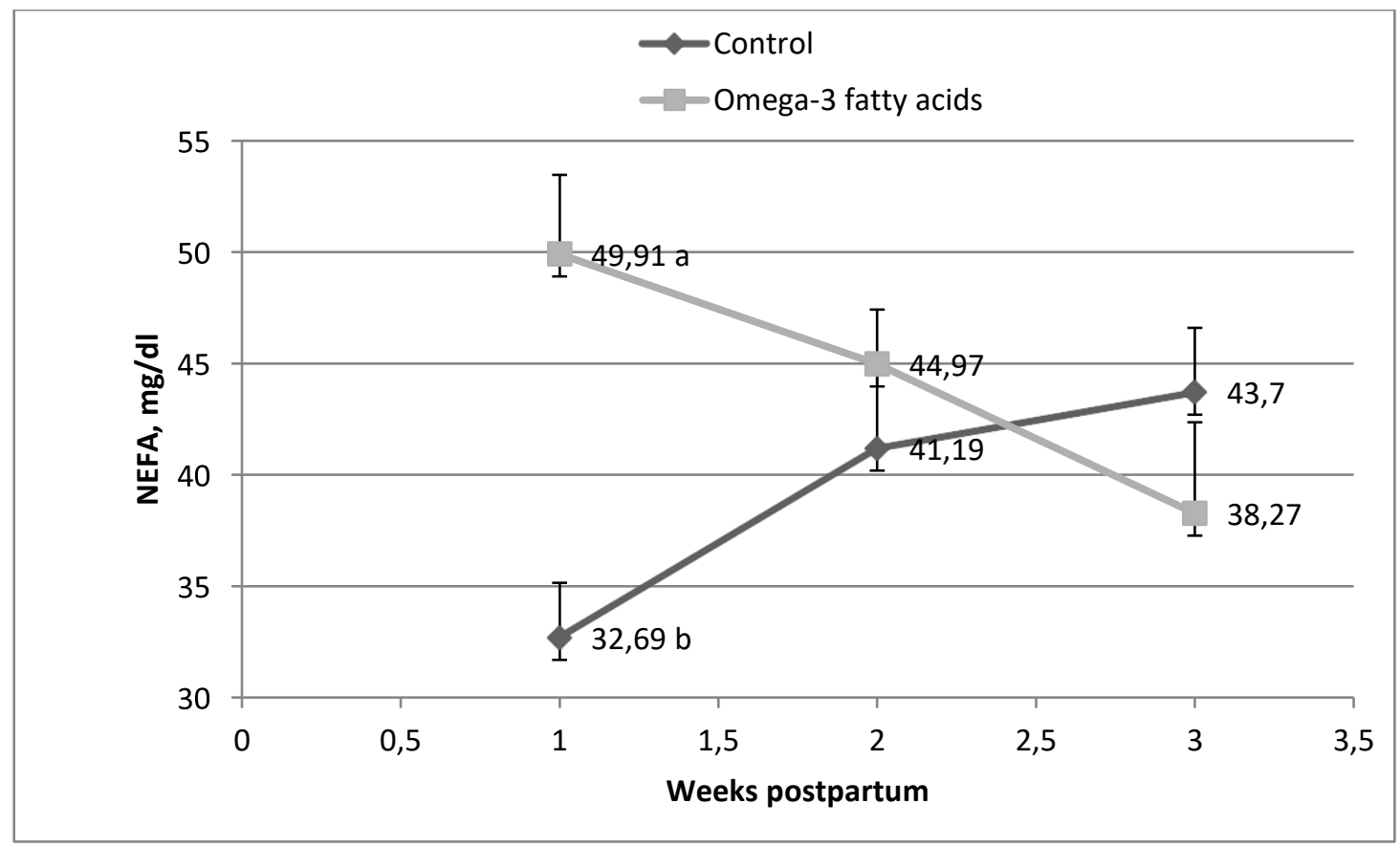

Figure 3: Influence of dietary omega-3 fatty acids on plasma non-esterified fatty acids (NEFA) concentration in fresh lactating cows

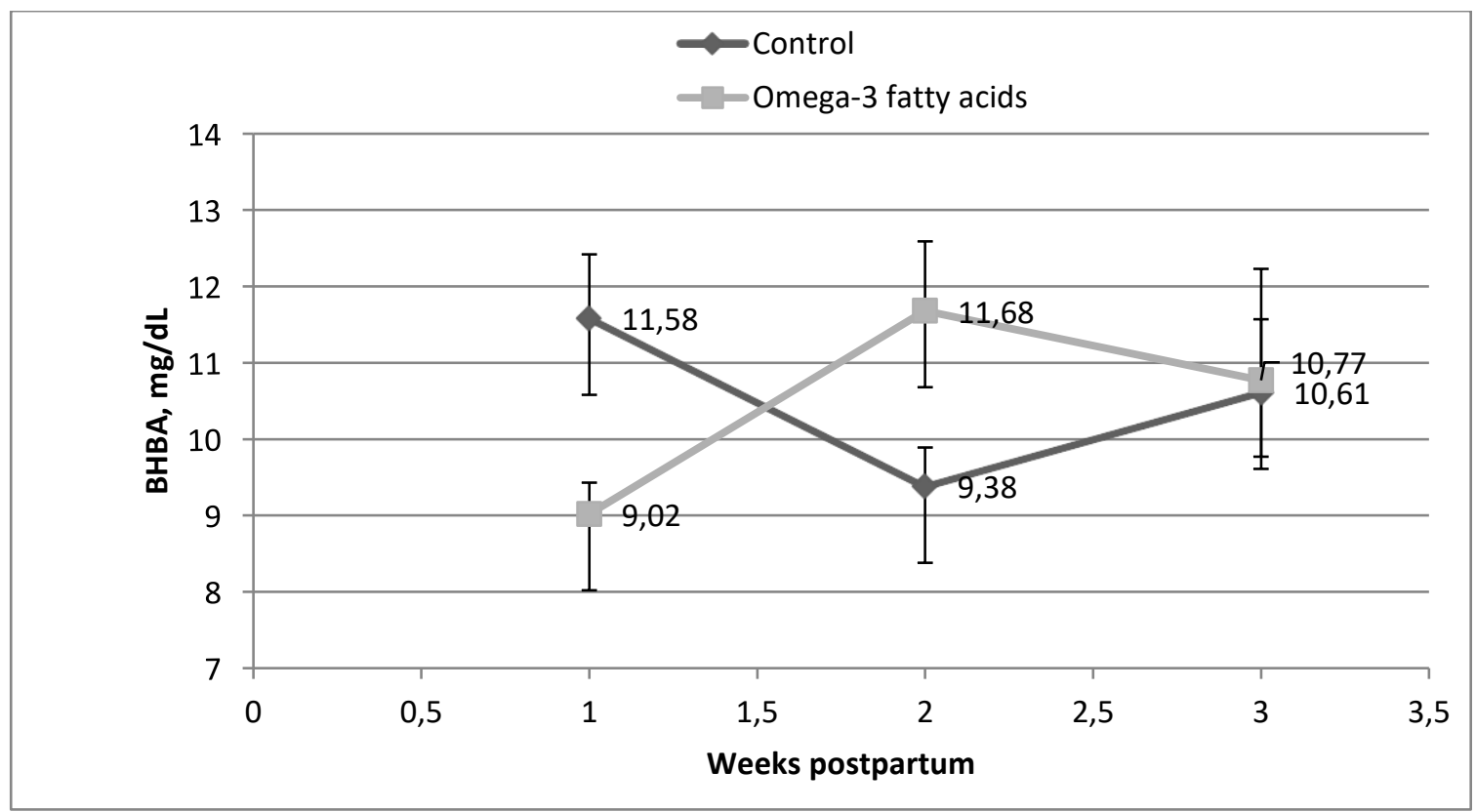

Figure 4: Influence of dietary omega-3 fatty acids on plasma beta hydroxyl butyric acid (BHBA) concentration in fresh lactating cows 


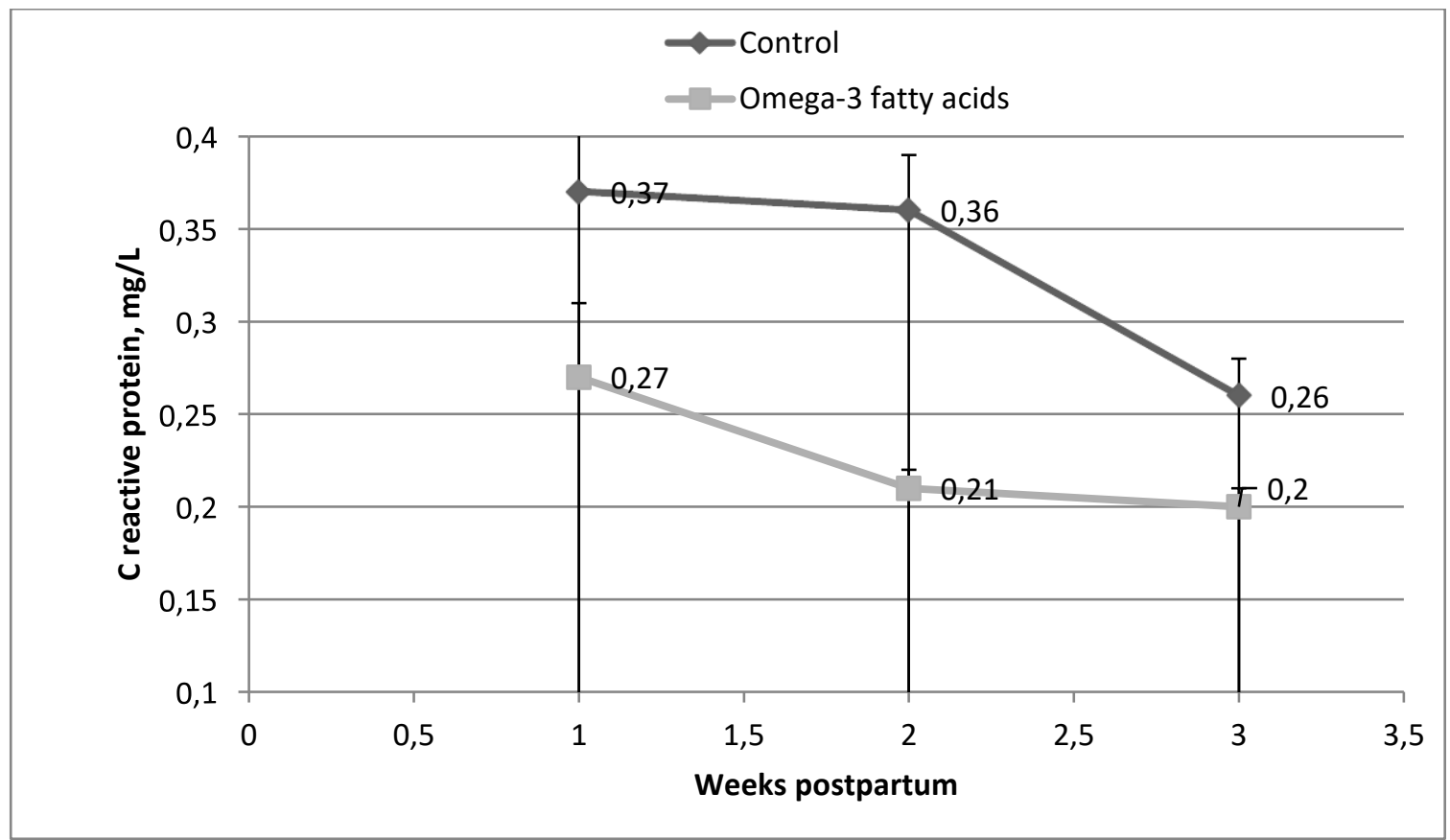

Figure 5: Influence of dietary omega-3 fatty acids on serum $\mathrm{C}$ reactive protein concentration in fresh lactating cows

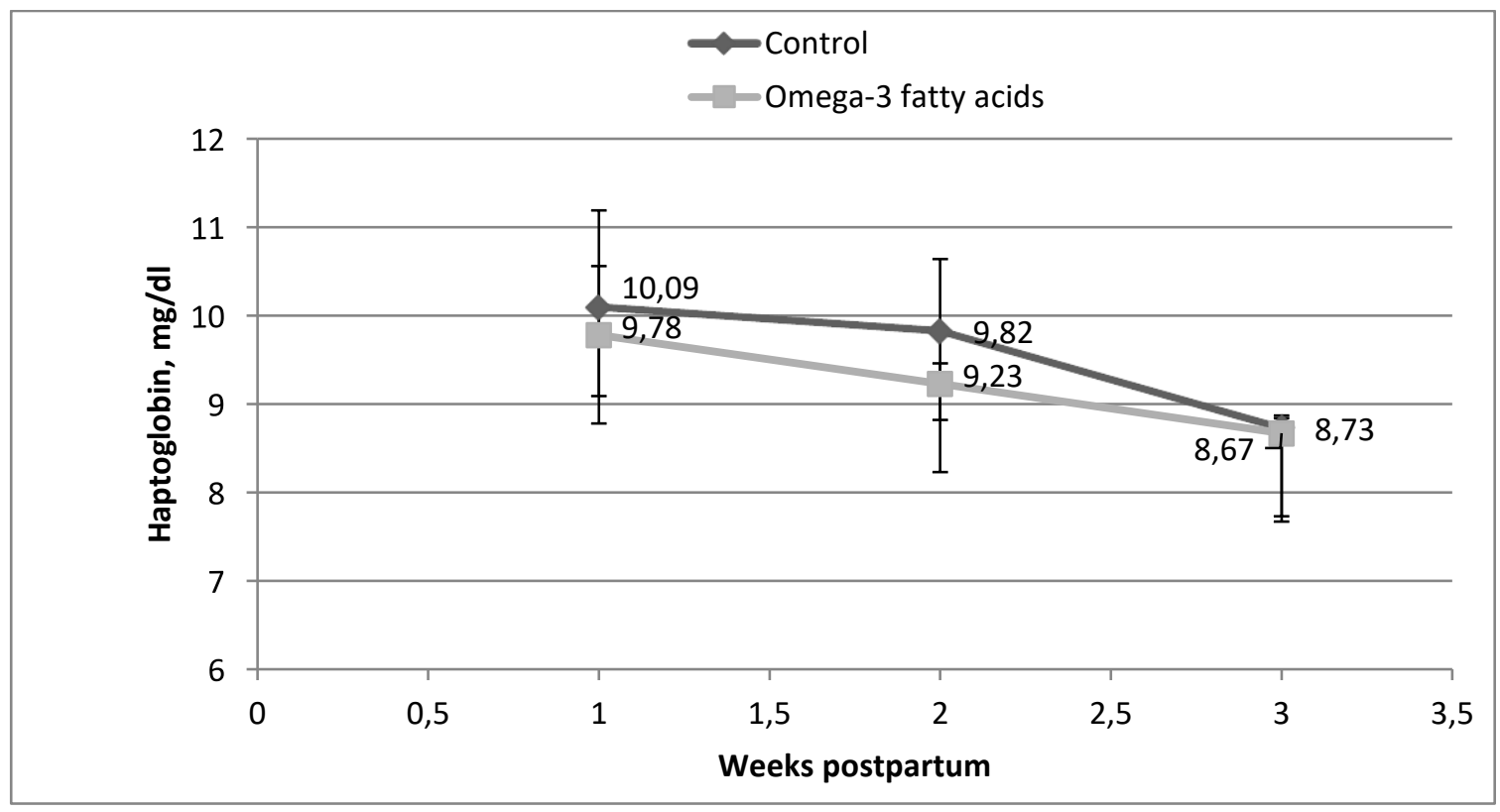

Figure 6: Influence of dietary omega-3 fatty acids on serum haptoglobin concentration in fresh lactating cows 


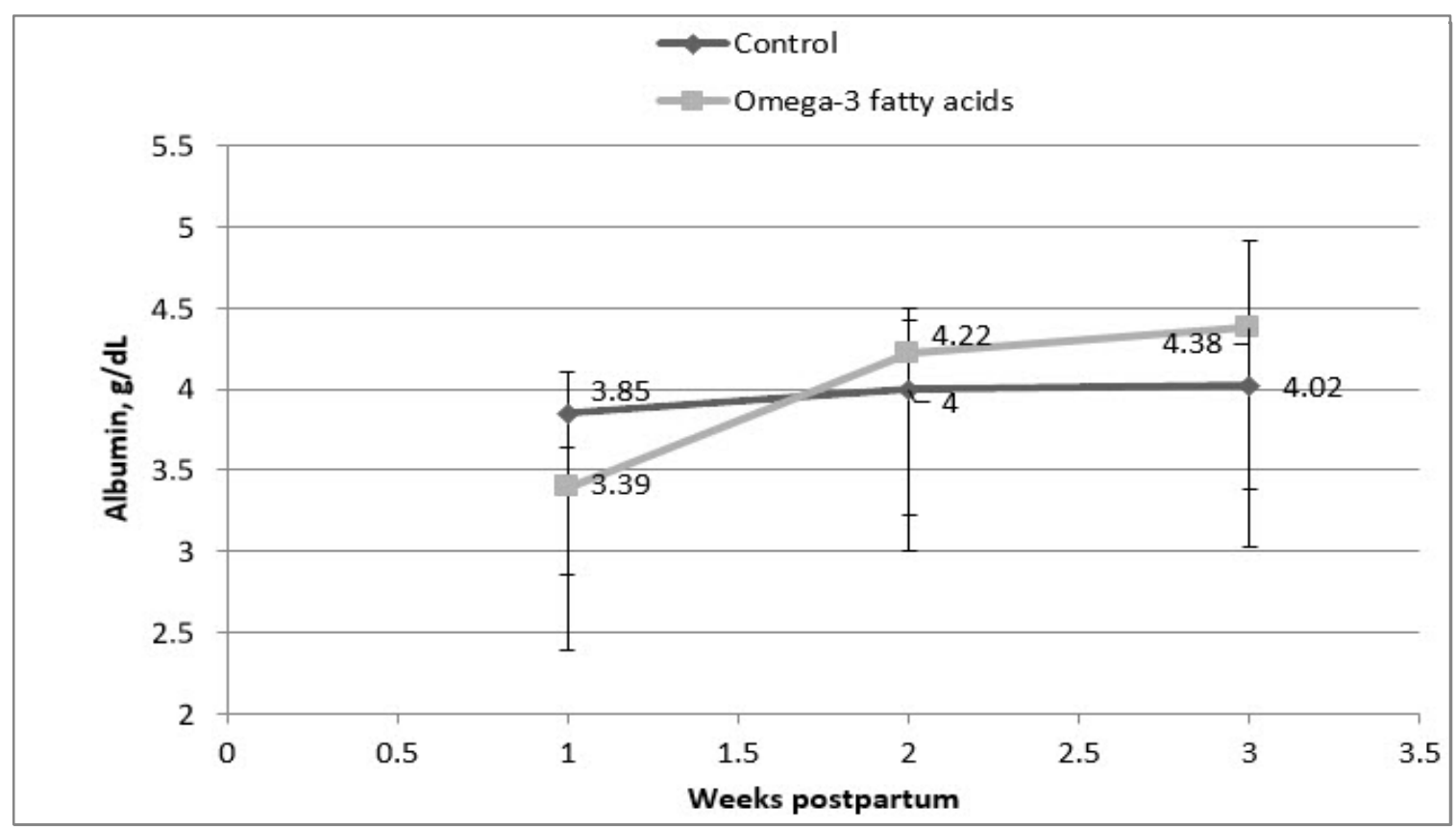

Figure 7: Influence of dietary omega-3 fatty acids on serum albumin concentration in fresh lactating cows

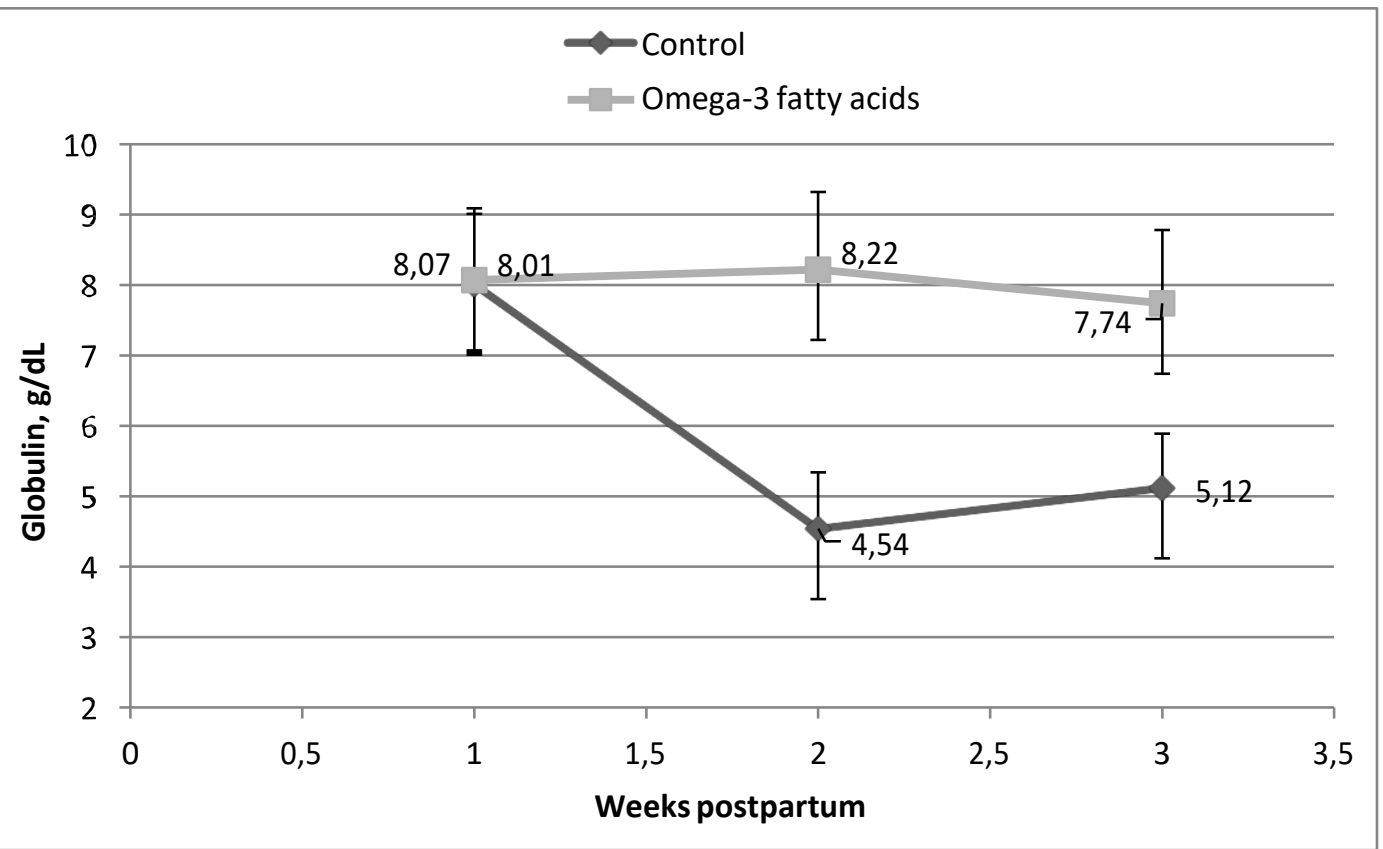

Figure 8: Influence of dietary omega-3 fatty acids on serum globulin concentration in fresh lactating cows

\section{Discussion}

Post calving cows suffering from many problems during the transition of these cows to lactation. In this period there is massive changes, more metabolic stresses for dairy cows and also more incidence of diseases and morbidity. Researchers reported that postpartum dairy cows suffering from systemic inflam- 
matory state (29). It is thought that the fatty acids of n-3 family improving metabolic profile of dairy cows and also attenuate measure of inflammatory response in lactating cows and so we conducted the present study to investigate their effects on inflammation and energy balance post calving.

It is well known that insulin concentration reflecting the glucose availability to stimulate beta cells of pancreas to produce and release insulin. The concentration of blood glucose with omega-3 feeding increased during the 3 weeks of the experiment with significant difference in $2^{\text {nd }}$ and $3^{\text {rd }}$ weeks of the trial. But, no significant effect was detected in the $1^{\text {st }}$ week of the trial between the control and the omega- 3 groups. The concentration of insulin was significantly increased at $1^{\text {st }}$ and $2^{\text {nd }}$ weeks of the trial at $\mathrm{P}$ value 0.015 and 0.029 respectively, for the omega-3 group and also increased in the $3^{\text {rd }}$ week but with no significant at $\mathrm{P}$ value 0.1 . (30) reported that omega-3 of fish oil decreased insulin response to glucose in rats and this finding may explain why the plasma glucose concentration increased with feeding of omega-3 of fish oil and this greater concentration of plasma glucose for cow fed omega-3 was the result of a better energy status. The result of glucose was in agree with $(31,32)$ and disagree with $(33)$ that reported a decrease in plasma concentration of glucose with feeding fish oil and also with (34) that observed no change in blood glucose concentration with feeding of 5\% fish meal and n3 fatty acids to early lactating cows. The past using fish meal or fish oil as a source of long chain omega 3 fatty acids for ruminants might expose these fatty acids to saturation by rumen microbes which led to loss of its functional importance in the metabolism. In contrast, our study used EPA and DHA which were protected from rumen microbes, passed to abomasum in which were hydrolyzed and absorbed without change through the intestinal tract. So the difference might be due to the dose of EPA and DHA which arrived the metabolic pool without saturation.

The result of insulin in the current study is in agree with (34) and disagree with (35) that noticed a reduction in insulin concentration in blood of dairy cows when fed fish oil containing DHA. Most of the changes occurred in plasma concentration of NEFA in the early lactation as the result of changes in adipose tissue mobilization and energy status (36).

In our study, the plasma concentration of NEFA was higher $(49.91 \pm 3.56 \mathrm{mg} / \mathrm{dl})$ in the $1 \mathrm{st}$ week in the omega-3 group. Then it rapidly declined in 2 nd $(44.97 \pm 2.45 \mathrm{mg} / \mathrm{dl})$ and $3 \mathrm{rd}$ $(38.27 \pm 4.09 \mathrm{mg} / \mathrm{dl})$ week. In contrast to the control group which was the lowest concentration in $1^{\text {st }}$ week $(32.69 \pm 2.46 \mathrm{mg} / \mathrm{dl})$ and then increased till reached $43.70 \pm 2.90 \mathrm{mg} / \mathrm{dl}$. This was reflecting sever mobilization of fat from adipose tissue and also increasing the effect of negative energy balance while the decline of NEFA concentration in omega-3 group that reached to $38.27 \pm 4.09 \mathrm{mg} / \mathrm{dl}$ reflecting an improvement in the energy status and metabolic profile.

The result in current study of NEFA concentration was in agree with (33) that noticed a decrease in NEFA concentration by 21 day postpartum with cows that fed fish oil, and also agreed with (37) that reported a high concentration of plasma NEFA in the $3^{\text {rd }}$ week postpartum and then gradually decreased with omega3 feeding. The result of plasma NEFA disagreed with (31) which reported a high plasma NEFA concentration with cows fed calcium soap of fatty acids and also stated that feeding them did not improve the energy status of early lactating cows. Also our study disagreed with (38) that reported high concentration of plasma NEFA in all groups that fed omega-3 compared to the control group. However, our findings agreed with (39) who observed a great increase in plasma NEFA concentration in the $2^{\text {nd }}$ week post-partum and then decreased gradually. The differences among studies might be due to the type, dose and technology of protection of fatty acids used in the fat supplement.

BHBA is one of ketone bodies that produced by the liver as a result of incomplete oxidization of fat. Elevated BHBA above $14 \mathrm{mg} / \mathrm{dl}$ indicate ketosis that had impact on both cow health and milk yield. In the current study, BHBA in plasma was lower in cows fed omega-3 FA at $1^{\text {st }}$ week at P-value 0.016 and then slight increase with no clinical ketosis at level 11.7 
$\mathrm{mg} / \mathrm{dl}$. Then it decreased to become nearly the same to the control group at the end of experiment at P-value 0.576. In agreement, (37) and (40) also reported that cows fed flax seed were in positive energy balance that indicated by a lower BHBA, NEFA and high glucose concentration. In contrast, (33) stated that the concentration of BHBA in plasma in cows fed fish oil increased with the increasing days postpartum $(\mathrm{P}<0.02)$. The same result of the current study agreed with (12) who reported an increase in plasma concentration of glucose and decreased plasma ketones in fresh cows that fed flax seed (omega-3) compared to omega-6 and adding that the anti-inflammatory effect of omega-3 source resulted in increased phagocytic activity of leucocytes and thus omega-3 source could improve metabolic and immune function.

Acute phase proteins (APP) are a group of glycoproteins produced by liver in respond to an inflammatory stimulus, infection or trauma in animals (41). APP stimulate immunoglobulin production, tissue repair and prevent more injury (42). Results of APP including C-reactive protein (CRP) and haptoglobin (HP) in the current study are found in figures 5 and 6 respectively.

The mean of serum concentration of CRP ( $\mathrm{mg} / \mathrm{l}$ )was lower in cows supplemented with omega- 3 in the $1^{\text {st }}$ and $2^{\text {nd }}$ weeks of experiment $(0.27$ and 0.21$)$ respectively than the control group, and at the $3^{\text {rd }}$ week of the trial there were no significant difference between control and omega-3 groups. The reduction in serum CRP in the $1^{\text {st }}$ and $2^{\text {nd }}$ weeks in the cows supplemented with omega-3 indicated that omega-3 has an anti-inflammatory effect. The same results was reported by (6) that noticed an antiinflammatory effect when cows fed n-3 fatty acids from fish oil illustrated by decreased acute phase proteins.

The means of haptoglobin concentrations during the 3 weeks of experiment not significantly differ between control and omega-3 group and this in agree with (43) and dis agree with (44)that stated that haptoglobin was a sensitive marker of inflammation in cattle. A low levels of haptoglobin was documented by (6) when cows fed fish oil from 35 to 160 days postpartum. The difference of results in this study and other studies may be due to different level of addition of omega-3, different omega3 sources or time of addition omega- 3 .

Blood serum proteins are significant indicators of animal health. There was no significant difference in the mean of serum globulin level in the $1^{\text {st }}$ week of trial between control and experimental groups while in the $2^{\text {nd }}$ and $3^{\text {rd }}$ weeks there was a significant increase in the means of serum globulin in the cows supplemented with omega-3. These results indicate that omega-3 fatty acids are very important for humoral immunity. However, no difference in serum albumin was observed between control and experimental groups.

Further study will be conducted regarding with effect of omega 3 fatty acids on milk yield, persistency and reproductive performance of lactating cows. Also recording metabolic problems, cost of treatment and culling to evaluate economic importance of omega 3 fatty acids in lactating

\section{Conclusion}

Feeding omega-3 FA tended to increase blood glucose and insulin levels in lactating cows and decrease the plasma level of NEFA gradually in the blood from $2^{\text {nd }}$ to $4^{\text {th }}$ week postpartum. There was a significant decrease in serum $\mathrm{C}$ - reactive protein in the cows fed omega3 FA. Also, omega 3 FA improved humoral immunity by increasing serum globulin. Finally feeding dairy cows with EPA and DHA fatty acids during transition to lactation minimized inflammatory response post calving and improved their energy status.

\section{Conflict of interest}

The authors declare that they have no conflict of interest.

\section{References}

1. Piccione G, MessinaV, Marafioti S, Casella S, Giannetto $\mathrm{C}$ and Faziof. Changes of some haemato chemical parameters in dairy cows during late gestation, postpartum, lactation and dry periods. Vet. Med. Zoot. 2012; 58, 59-64.

2. Wathes DC, Cheng Z, Chowdhury W, Fenwick MA, Fitzpatrick R, Morris DG, Patton J and 
Murphy JJ. Negative energy balance alter global gene expression and immune responses in the uterus of postpartum dairy cows. Physiol Genomics, T. 2009; 39:1-13.

3. Humblet MF, Guyot H,Boudry B, Mbayahi F, Hanzen C, Rollin F, and Godeau JM. Relationship between haptoglobin, serum amyloid $\mathrm{A}$, and clinical status in a survey of dairy herds during a 6-month period.Vet. Clin. Pathol. 2006; 35:188-93.

4. Scalia D, Lacetera N, Bernabucci U, Demeyere K, Duchateau L and Burvenich C. Invitro effects of nonesterified fatty acids on bovine neutrophils oxidative burst and viability.J. Dairy Sci.2006; 89: 147-54.

5. Contreras GA, Rephael WS, Mattmiller A, Gandy J, and Sordillo LM. Non esterified fatty acids modify inflammatory response and eicosanoid biosynthesis in bovine endothelial cells. J. Dairy sci.2012b; 95:5011-23.

6. Silvestre F, Carvalho PC, Crawford JE, Santos P, Staples CR, Jenkins T, and Thatcher WW. Effects of differential supplementation of fatty acids during the peri partum and breeding periods of Holstein cows: II .Neutrophil fatty acids and function, and acute phase proteins .J. Dairy sci.2011; 94:2285-301.

7. Calder PC, Yaqoop, Thies F, Wallace FA, Miles EA .Fatty acids and lymphocyte functions.Br.J.Nutr.2002; 87:S31-48.

8. Clarke SD. The multi-dimensional regulation of gene expression by fatty acids: poly unsaturated fats as nutrient sensors.Curr.opin.Lipid.2004; 15:13-8.

9. Lee JY, Zhao L, and Hwang DH. Modulation of pattern recognition receptor-mediated inflammation and risk of chronic diseases by dietary fatty acids.Nutr.Rev.2010; 68:38-61.

10. Oh DY, Talukdar S, Bae EJ, Imamure T, Morinaga H, Fan W, Li P, Lu WJ, Watkins SM, and Olefsjy JM.GPR120 IS an omega-3 fatty acid Receptor Mediating Potent Anti-Inflammatory and insulin-sensitizing Effects. Cell. 2010; 142 (5):68798.

11. Calder PC. Mechanisms of action of (n-3) fatty acids. J. Nutr. 2012; 142: 5925-95.

12. Gandra JR, Barletta RV , Mingoti RD, Verdurico LC, Freitas JE, Oliveira L J ,Takiya CS, Kfoury JR, Wiltbank MC, and Renno FP. Effects of whole flaxseed ,raw soybeans , and calcium salts of fatty acids on measures of cellular immune function of transition dairy cows .J. Dairy Sci. 2016a; 99:4590-606.
13. Dirabdeh E,Towhidi A, Zein oaldin IS, Ganj khanoul M,Ansaripirsaraei Z,Fouladi-Nashta A.Effects of different polyunsaturated fatty acids supplementations during the postpartum periods of early lactating dairy cows on milk yield ,metabolic responses, and reproductive performances. J. Anim.Sci.2013; 91:713-21.

14. Gifford CA, Holland BP, Mills RL, Maxwell CL, Farney JK, Terrill SJ, Step DL, Richards CJ, Burciaga Robles LO, and Krehible CR. Impacts of inflammation on cattle growth and Carcass merit. J. amin. Sci. 2012; 90:1438-51.

15. National Research Council .Nutrients of Dairy Cattle $.7^{\text {th }}$ Rev. Ed.Natl. ACAD.Sci.2001; Washington, DC.

16. Associations of Official Analytical Chemists. Official Methods of Analysis $.16^{\text {th }}$ Ed.AOAC1995; Arlington .VA.

17. Vansoest PJ, Robert son JB and Iewis BA. Methods for dietary fiber, neutral detergent fiber and non-starch polysaccharides in relation to animal nutrition .J. Dairy .Sci.1991; 74:3583-97.

18. Hintz RW and Mertens DR. Effects of sodium sulfite on recovery and composition of detergent fiber and lignin. J.AOAC Int.1996; 79: 16.

19. Association of Official Analytical Chemists. Official Methods of Analysis 1991; 74:81.

20. Abdellatif K R A, Fadaly W A A, Kamel G M, Elshaier Y A M M, El-Magd M A. Design, synthesis, modeling studies and biological evaluation of thiazolidine derivatives containing pyrazole core as potential anti-diabetic PPAR- $\gamma$ agonists and antiinflammatory COX-2 selective inhibitors, Bioorganic Chemistry 2019; 82: 86-99.

21. Smith and Wilson. Free fatty Acids and Atherosclerosis. J. Clin .Endocrinal Metab 2006; 91: 2506-8.

22. Murray $\mathrm{CH}$, Blanchflower WJ, and Rice DA.Clinical chemistry.3013, 421; 1984.

23. Burtis CA Tietz Text book of clinical chemistry, $3^{\text {rd }}$ ed, AACC 1999.

24. Reinhold RR. Determination of serum albumin.clin.chem.1953; 21:1370-1372.

25. Coles EH: Vet. Clin.Path.1974; 211213.W.B.Sounders Company Philadelphia, London,Toronto.

26. Chu CC, Lee SL and Fung HP. Purification, analysis and basal level of serum haptoglobin in cattle.P.88.In: Congress of the Taiwan Association of Veterinary Medicine and Animal Husbandry, Taiwan.2002.

27. Burtis CA, Ashwood ER,Titez Text book of clinical chemistry. $2^{\text {nd }}$ Edition, W.B. Saunders, Philadelphia, PA (1994). 
28. Eatham RD: Biochemical Values in Clinical Medicine, $7^{\text {th }}$ Ed. Bristol. England John Wright\&sons,Ltd: 1985.

29. Humblet MF, Guyot H,Boudry B, Mbayahi F, Hanzen C, Rollin F, and Godeau JM. Relationship between haptoglobin, serum amyloid A,and clinical status in a survey of dairy herds during a 6-month period.Vet.Clin.Pathol.2006;35:188-93.

30. Pighin D, Kara batas L, Rossi A, Chicco A, Basabe JC, Lombardo YB,2003.Fish oil affects pancreatic fat storage, Pyruvate dehydrogenase complex activity and insulin secretion in rats fed a sucrose -rich diet.J.Nutr.2003;133:4095-101.

31. Juchem SO, Santos JEP, Cerri RLA, Chebel RC, Galvao KN, Bruno R, Depeters EJ, Scott T , Thatcher WW, Luchini D. Effect of calcium salts of fish and palm oils on lactational performance of Holstein cows .Ani.feed .Sci.2008;140:18-38.

32. Gandra JR, , Mingoti RD, Barletta RV, Takiya CS , Verdurico LC, Freitas JE ,Paiva PG, Jesus EF, Calomeni GD and Renno FP . Effects of flaxseed ,raw soybeans, and calcium salts of fatty acids on apparent total tract digestibility, energy balance and milk fatty acid profile of transition cows .Animal.2016b;1:1-8.

33. Mattos R, Staples CR, Arteche A, Wiltbank MC, Diaz FJ, Jenkins TC and Thatcher WW. The effects of feeding fish oil on uterine secretion of PGF2 $\alpha$, Milk composition, and metabolic status of periparturient Holstein cows.J.Dairy .Sci.2004; 87:921 -32.

34. Heravi Moussavi AR, Gilbert RO, Verton TRO, Bauman DE and Butler WR. Effects of feeding fish meal and n-3fatty acids on milk yield and metabolic responses in early lactating dairy cows J.Dairy sci. 2007; 90:136-44.

35. Bilby TR, Sozzi A, Lopez MM, Silvestre FT, Ealy AD, Staples CR\& Thatcher WW. Pregnancy, bovine somatotropin, and dietary n-3 fatty acids in lactating dairy cow: I. Ovarian, conceptus, and growth hormone - insulin -like growth factor system responses .Journal of dairy Sci. 2006b; 89: 3360-74.

36. Drackley JK. Biology of dairy cows during the transition period; the final frontier? J. Dairy Sci.1999; 82:2259-73.
37. Greco LF, Neves Neto JT, Pedrico A, Ferraza RA, Lima FS, Bisinotto RS, Martinez N, Garcia M, Ribeiro ES, Gomes GC, Shin JH, Ballas MA, Thatcher WW, Staples CR, and Santos JEP. Effects of altering the ratio of dietary n-6 ton-3 fatty acids on performance and inflammatory responses to a lipopolysaccharide challenge in lactating Holstein cows.J.Dairy Sci.2015;98:602-17.

38. Gonthier C, Mustafa AF, Ouellet DR, Chouinard PY, Berthiaume R, and Petit HV. Feeding Micronized and extruded flaxseed to dairy cows. Effects on Blood parameters and milk fatty acid composition .J.Dairy Sci.2005; 88:746-56.

39. Elis S, Freret S, Desmarchais A, Maillard V, Cognie J, Briant E, Touze JL, Dupont M, Faverdin $\mathrm{P}$, Chajes V, Uzbekova S, Monget P and Dupont J. Effect of a long chain n-3PUFA-enriched diet on production and reproduction variables in Holstein dairy cows. Animal Reproduction Sci.2016; 164:121-32.

40. Ulfina GG, Kimotni SP,Oberoi PS, Baithalu RK, Kumaresan A, Moohanty TK, Imtiwati P and Dang AK. Modulation of post-partum reproductive performance in dairy cows through supplementation of long-or short -chain fatty acids during transition period JPn.2015;99,1056-64.

41. Marinkovic S, Jahreis GP, Wong GG and Baumann H. IL-6 modulates the synthesis of a specific set of acute phase plasma proteins in vivo .J.Immunol.1989; 142:808-12.

42. Kent JE. Acute Phase Proteins: their use in Veterinary diagnosis .Br.vet.J.1992; 148:279-82.

43. Staples CR, Amaral B, Silvestre F, Caldari Torres C, Cullens FM, Badinga L, Arthington JD and Thatcher WW .2008.Immune system responses to diseases /Disorders in the dairy animal and potential effects of essential fatty acids Florida Ruminant Nut.symp.2008;F1 32611,352-92.

44. Nazifi S, Rezak hani A, Koohimoghadam M, Ansari-Lari M and Esmailnezhad Z. Evaluation of scrum haptoglobin in clinically healthy cattle and cattle with inflammatory diseases in Shiraz, a tropical area in Southern Iran. Bulg. J. vet. Med. 2008;11, No2, 95-101. 